DOI https://doi.org/10.18551/rjoas.2018-05.17

\title{
ETHNOMETHODOLOGY STUDY ON THE PRACTICE OF INFORMAL ACCOUNTING INFORMATION SYSTEMS IN LOCAL GOVERNMENT: A STUDY IN BARITO REGENCY, SOUTH KALIMANTAN PROVINCE, INDONESIA
}

\author{
Hidayati ${ }^{\star}$, Triyuwono Iwan, Baridwan Zaki \\ University of Brawijaya, Indonesia \\ *E-mail: hdyt.hasan@gmail.com
}

\begin{abstract}
The purpose of this study is to comprehend and portray the practice of informal accounting information systems within a government organization. The results of this study found that informal accounting information systems in the public sector were a system with no written procedures and policies, but conducted spontaneously, without any arrangement and agreement within the organizational structure. Informal accounting information systems in the public sector were conducted through interactions among staffs, discussions in an unplanned meeting, and the use of social media as a means of coordination. In addition, informal accounting information systems in the public sector were also practiced through improvisations such as the use of personal notes, reporting schedules creation, and financial reporting checklists aimed at supporting the effectiveness of accounting information system practices.
\end{abstract}

\section{KEY WORDS}

Accounting, information systems, informal, public sector.

Up to now, research on accounting information systems generally focuses on technology or software used to support the practice of an organization's accounting information systems. In addition, research on accounting information systems generally comes from research with a positivist paradigm (Roberts and Scapens, 1985). Compliance with any paradigms, such as that of information systems researchers in general, would make the research repository becomes inundated and weak (Wijaya et al., 2015).

Most researchers argue that accounting information systems are existing information systems within rational organizations (Button et al., 2012). This interpretation leads to the belief that the system will follow the previously outlined path (Roberts and Scapens, 1985).

In fact, the information systems not only cover the various structures and operational procedures but also involve humans (Vickers, 1999). The human element involvement triggers differences in the information system perception (Roberts and Scapens, 1985).

Preston (1996) states that in the information system, there is an information delivery process fundamentally different from the formal information system as described in the traditional literature. This process of delivering information is an unstructured process, largely based on personal interaction. Preston indicates that the process of information delivery refers to the social order rather than the formal order.

Further, Burns (1969) shows that there is a plurality of social systems within an organization. Such system can be seen as a socially constructed order (Berger \& Luckmann, 1969) or be built by the environment. The social order consists of patterns of relationships, meanings, and interpretations formed and created a "sense" of individual interactions. Social order in the process of using information system becomes interesting to be studied. The social order in information systems is a phenomenon has not been widely explored (Wijaya et al., 2015).

According to Febriansyah (2014), it is still not much research regarding information systems in the public sector accounting domain in Indonesia. Based on the above 
description, the researchers aim to examine and investigate more deeply about the informal information systems in the process of information systems utilization in the government sector.

The researchers chose the Regional Finance and Asset Management Agency (Badan Pengelola Keuangan dan Aset Daerah, BPKAD) of Barito Kuala Regency as the research location because of the daily interaction in BPKAD of Barito Kuala Regency used local language, i.e. the Banjar Language. The researchers' language and cultural similarities with the organization were significant in order to comprehend daily communication in the practice of informal accounting information systems in BPKAD of Barito Kuala.

Informants in this study were accountant staffs fully/actively involved in accounting work practices in BPKAD of Barito Kuala Regency.

Table 1 - List of Staff of BPKAD Barito Kuala as Informant Research

\begin{tabular}{|l|l|l|}
\hline No. & \multicolumn{1}{|c|}{ Name } & \\
\hline 1 & Mr. BN & Position \\
\hline 2 & Mr. AR & Head of BPKAD \\
\hline 3 & Mr. RP & Head of Bookkeeping Sub-division \\
\hline 4 & Ms. ASR & Staff of Reporting Sub-division \\
\hline 5 & Ms. SK & Staff of Bookkeeping Sub-division \\
\hline 6 & Mr. AN & Staff of Bookkeeping Sub-division \\
\hline
\end{tabular}

\section{METHODS OF RESEARCH}

The practice of informal accounting information systems is closely related to human actions (the accountant staffs). To examine the human sciences more deeply, a researcher must use the right method to reveal the scientific truth correctly so the meaning of the object becomes better and not stuck in an emotional situation (Budianto, 2002: 69). Therefore, this research used ethnomethodology as the method.

Some literature states that ethnomethodology is one of the perspectives within the interpretive paradigm (see Denzin and Lincoln, 2009: 338; Coulon, 2008: 3; Ritzer and Goodman, 2012: 419). The emergence of ethnomethodology begins with the works of sociologist Harold Garfinkel (Ritzer and Goodman, 2012: 418).

According to Garfinkel, ethnomethodology is used for the investigation or interpretation of indexicality and other practical actions as a complete unity of the practices undertaken in everyday life in an organized manner. In other words, Garfinkel's ethnomethodology aims to examine the social interactions in everyday life usually taken for granted, filled with assumptions, and had a shared meaning.

\section{DISCUSSION OF RESULTS}

Interaction Portrait in the Practice of Accounting Information Systems. After the researchers mingled in BPKAD of Barito Kuala Regency for one week, the researchers found that much important information was delivered in informal information channels through verbal interaction conducted in daily work practices. One of the staffs revealed the number of special allocation funds they received. The researchers were particularly interested in how the information was transferred through verbal communication. Through the interview, the researcher confirmed the information with Mr. AR. The researcher asked whether the information presented by the staff will be enclosed in the official financial statements (in this case, the financial statements produced by the accounting software). Mr. AR replied: "Of course, the information related to the allocation fund will be reported in the financial report".

The indexical statement stated by Mr. AR "The information related to the allocation fund will be reported in the financial report" had the reflexivity meaning that the information conveyed through verbal communication between the employees provided 
information faster than the information generated through the official computerized report in SIMDA (Regional Management Information System, Sistem Informasi Manajemen Daerah) financial applications. The researchers analyzed the very important yet informal information exchange and concluded that formal accounting information systems were operated within the informal information systems, i.e. the relationship between employees.

In line with the statement, the researchers confirmed with Mr. BN as the head of BPKAD regarding the information he received so far. Mr. BN stated that some of the information he received was not all from official documents. He stated that: "I know most of the financial information is communicated verbally, for example, the IDR billions of the Special Allocation Fund/General Allocation Fund, while the report has not been received. Later, the report is published at the end of the month".

In line with Mr. AR's statement, the indexical statement stated by Mr. BN "I know most of the financial information is communicated verbally" had the reflexivity meaning that the information conveyed through verbal communication between employees provided information faster than information generated through computerized official reports. Further, Mr. BN added: "The financial statements are used later to synergize with the center. In practice, informal information is more important".

The indexical statement stated by Mr. BN "The financial statements are used later to synergize with the center. In practice, informal information is more important" had the reflexivity meaning that he as the head of BPKAD preferred the verbal information more, because verbal media provided higher flexibility, required less effort, and responded more quickly.

Some of these statements illustrated that some information was first known through the daily interactions between staffs. In this case, it seemed that the official information document produced by SIMDA only confirmed what they already knew and made the information the official document presented was no longer "surprising" because the staffs already knew most of the information in the document.

Social Media Utilization. The use of social media has formed and supported new ways of communicating, interacting, and collaborating. Social media offers a faster and more convenient way to participate in the information exchange through the network/online. With its advantages and convenience, social media is popularly used by many people. Social interaction can be done through digital communication and the presence of social media makes social interaction through digital communication becomes very popular. Through social media, users can perform a variety of social interactions, whether in entertainment, education, health, or work.

"Ting nong... ting nong" was the sound the researchers often heard between work time. It became a fresh joke among staffs in the accounting room of BPKAD of Barito Kuala Regency. The frequent sound from Ms. ASR's mobile phone caused Mr. ASN to tease her frequently. Besides, Ms. ASR is the most sociable and the youngest among the other staffs.

"Your hp just can't stop ringing. I wonder who calls you", joked Mr. ASN, causing the laughter of other staffs. His jokes revived the warm atmosphere in the accounting practice in Barito Kuala Regency. In response, Ms. ASR replied: "It's an official business, Sir, not something odd. If you do not believe me, just look at this," said Mrs. ASR while showing her phone displaying WhatsApp chat group communication entitled Batola Financial Information.

In response, the researchers conducted an interview with Ms. ASR regarding the communication in her WhatsApp. Ms. ASR replied: "I use WhatsApp to ask SKPD to come here. I know the financial statement updates via WhatsApp also".

The indexical statement stated by Ms. ASR "...I know the financial statement updates via WhatsApp also" had the reflexivity meaning that the presence and development of social media brought new ways of communicating in the accounting practices of BPKAD of Barito Kuala. Although not in the formal order, communication through WhatsApp messenger provided updated information about accounting activities 
in SKPD (Local Government Work Unit, Satuan Kerja Perangkat Daerah) environment. It was because communication through WhatsApp was not limited by distance, space, and time and happened anywhere and anytime, without having to talk directly or face to face.

The researchers once found an advertisement from one internet service provider stated "World is in your hand", which is relevant in the modern society era. The presence of the internet as a medium of modern communication has made the world becomes more easily accessible. Almost everyone has a communication tool, making one is able to communicate with another through social media. One of them is through a cross-platform messaging application allowing users to exchange messages without the SMS cost i.e. WhatsApp Messenger.

Related to this, the researcher confirmed through an interview with Mr. AR, following Mr. AR's statement regarding the use of WhatsApp in his work:

"The use of communication media nowadays has grown so rapidly along with the advancement of communication technology, in which we are faced with many options to be able to convey and access information. WhatsApp group is an alternative".

The indexical statement stated by Mr. AR "...many options to be able to convey and access information. WhatsApp group is an alternative" had the reflexivity meaning that the accounting information exchange did not merely involve accounting documents. Although it looked simple, communication through WhatsApp had a significant impact on the financial communication between SKPD and BPKAD of Barito Kuala Regency. Communication could be done quickly without having to conduct a meeting directly.

In line with the previous statement, Mr. AR added further:

"WhatsApp Group simplifies our work, from job updates to delegation. Communication becomes faster, smoother, and known by many people at the same time. One message can be read together. The display is also simple. The information exchange about the work can be done quickly", he continued. He seemed to use WhatsApp often to exchange information.

Each stage of technological progress leads to a series of changes interacting with other changes arising from the technology system as a whole (Gouzali, 2005: 21). WhatsApp Messenger as a medium of communication for the information sharing source was used to transfer accounting information in BPKAD of Barito Kuala Regency. The accountant staffs in BPKAD of Barito Kuala Regency were interested in utilizing this application as an information source because this application could provide information related to work practices and the display looks simple enough to be used. WhatsApp Messenger application media was assumed to provide convenience in social interaction and coordination between BPKAD and local SKPD.

The rapid technological advances in communications have been well utilized by the accountant staffs in BPKAD of Barito Kuala Regency to facilitate the more effective communication process with SKPD. This is in line with Mintzberg's (1991) research that managers in fact often use the flow of information which does not fully utilize the accounting information systems formally.

Meeting as a symbiosis of mutualism. Nunung (2001: 129) states meeting is a form of face-to-face group communication media often organized by many organizations, including the governmental organizations. The meeting aims to achieve agreement through deliberations in decision-making.

BPKAD of Barito Kuala held the meetings for all staffs every once in a month. However, the meeting was not only the monthly meeting. The researchers conducted an interview with Mr. AR related to the meeting in BPKAD of Barito Kuala Regency. Mr. AR stated:

"The meetings are scheduled once a month, i.e. staff meetings. But in the accounting department, sometimes the meetings need to be held suddenly. We once held the meetings 2-3 times in a month (while chuckling). It usually happens when the process of making financial statements.

The indexical statement stated by Mr. AR "... but sometimes the meetings need to be held suddenly" had the reflexivity meaning that the meeting was held not based on a 
plan and could happen at any time. From the statement, the researchers concluded the meeting could be done informally to find the solutions for occurring accounting problems.

Mr. AR further stated:

"The meeting is like a symbiosis of mutualism (while laughing). For example, we report to the relevant governance head about slow reporting from SKPD. The governance head has the power to suppress the SKPD".

Unplanned meetings were usually executed by the accountant staffs in BPKAD of Barito Kuala Regency as a communication media to present complaints related to urgent accounting practices. Thus, the meetings were not only planned but the meetings can also be held in accordance with their needs about some urgent issues.

Transfer Knowledge: Through Financial Technical Guidance. BPKAD of Barito Kuala Regency as the leading sector of regional asset and finance management must make asset and finance management efforts carefully to realize the good regional asset and finance management. Education Institution Cares for Government Performance (Lembaga Pendidikan Peduli Kinerja Pemerintah, LP2KP) is an institution supporting government programs to provide solutions for the needs of provincial, municipal, district, sub-district, and village level government in providing technical guidance, training education, and seminars.

Financial technical guidance is needed in the local government in budgeting, management, allocation, administration, financial statements preparation, and accountability for the finance utilization for regional development.

BPKAD of Barito Kuala Regency conducted technical guidance (Bimbingan Teknis, Bimtek) on Administration of Regional Financial Management for SKPD's financial administration officers, expenditure treasurer, treasurer's assistant, and revenue treasurer in Government of Batola Regency. Unfortunately, the researchers did not attend the financial technical guidance directly because it was carried out before the researcher conducted the research in BPKAD of Barito Kuala Regency, i.e. on March $08^{\text {th }}, 2017$.

Seeing the enthusiasm the researchers showed regarding the technical guidance activities they could not join, Mr. AR provided an overview related to the technical guidance implementation. He stated:

"In the activity, the participants were given an explanation about the administration in general, direct expenditure, indirect expenditure, and revenue, including application implementation in the administration of expenditure treasurers. Thus, it was expected that the participants understood the regulatory provisions, duties, and responsibilities of financial administration and used the SIMDA application appropriately and effectively."

Financial technical guidance is an effort of Government of Barito Kuala Regency to improve the quality of human resources expected to provide additional understanding in the administration in general, including the applied practice of accounting information systems. The researchers confirmed to Mr. BN related the financial technical guidance. He stated:

"I ask all participants to follow the financial technical guidance carefully. I hope all participants can utilize this financial technical guidance as well as possible. They can ask the speakers for more clear information as well".

The indexical statement stated by Mr. BN "... they can ask the speakers for more clear information as well" had the reflexivity meaning that there was an opportunity for the staffs to discuss the financial management practices in order to improve their abilities, skills, and understanding of local financial management mechanisms including the practice of accounting information systems.

Improvisation Portrait in the Practice of Accounting Information Systems. BPKAD of Barito Kuala Regency is a reporting entity compiling 47 SKPD's financial statements which are reported to the above governments, i.e. the Regent, The Audit Board of Indonesia, the Ministry of Finance, and the Ministry of Home Affairs. The complexity of reporting raises an "art" in the practice of accounting information systems. The researchers saw some personal notes posted on the bottom of the computer used by 
the accountant staffs. The researchers then asked Mr. AN as a staff of bookkeeping sub-division who attached some memos on his computer.

"These notes act as a reminder [while pointing to one note]. It is difficult if there is none, the older the more senile," said Mr. AN with a chuckle.

The indexical statement stated by Mr. AN "... It is difficult if there is none, the older the more senile" had the reflexivity meaning that there was improvisation used by staffs to "inform themselves", i.e. recalls of the occurred accounting activities. The researchers felt that the chuckle from Mr. AN when mentioning "the older, the more senile " is a form of recognition of his old age.

Furthermore, Mr. AN explained:

"It is one of the notes," said Mr. AN while addressing the note about some invalid SKPD's financial statements.

Knowing that the researcher observed the note, Mr. AN kindly explained:

"At the end of the year, there is usually a difference in cash flow outside the budget mechanism, so this little note is useful to remind us of occurred events. For example, unexpected transactions such as transfer errors, SKPD make the tax payments to the local government treasury instead of the state budget. We usually record such kind of errors".

The accountant staffs made some notes because they could not remember all occurred accounting events. Notes were used to record accounting events relevant to the work days and can be seen again when forgotten or needed. Personal notes are a private property. Therefore, it was not specified to what extent personal notes were made in the process of accounting information systems in BPKAD of Barito Kuala Regency.

On Wednesday, November $1^{\text {st }}, 2017$, when the researchers were with the staffs of BPKAD's accounting division, some employees who did not seem to be BPKAD employees entered the accounting room. The researchers who were not familiar with their faces asked Ms. ASR about who they are and what their intentions. The researchers' questions were so to the point that Ms. ASR replied "you really want to know, eh" while laughing, causing the researchers also laughed. The researchers only said to themselves that the presence of the researchers indeed to acquire the information deeply.

Communicating with Ms. ASR was one of the routines the researchers often did because of not much age difference between Ms. ASR and the researchers, making the communication was comfortable. Ms. ASR justified the researchers' opinion about the non-BPKAD staffs. Ms. ASR stated:

"That is the staffs from the Health Department. They come here because they need to report something".

Then the researcher asked whether their arrival was scheduled or random, while chewing the snacks on her desk, Ms. ASR replied:

"To facilitate the reports collections, we make some scheduled arrival for each SKPD. But sometimes, the staffs of some SKPD come over the schedule we have provided because they think something is unclear or they want to discuss something related to reporting".

In addition to the assistance agenda provided for SKPD, BPKAD staffs also provided a checklist of any documents which must be collected. Ms. ASR stated:

"In addition to the assistance schedule, we also provide documents checklist SKPD must complete related reporting".

The researcher confirmed to Mr. AR regarding work practices using assistance checklist and schedule of SKPD. Mr. AR stated:

"Making assistance checklist and agenda were our improvisations to simplify the process of accounting information systems".

The indexical statement stated by Mr. AR "Making assistance checklist and agenda were our improvisations to simplify the process of accounting information systems" had the reflexivity meaning that there was a method outside the procedure or 
done informally in the practice of accounting information systems. This was done in the presence of an "additional method" by the accountant staffs with the aim of emphasizing discipline in the timeliness of reporting and the completeness and accuracy of documents submitted by the SKPD. Improvisation in the work practice aimed to facilitate the practice of accounting information systems in BPKAD of Barito Kuala Regency.

"Accounting is an art" is a sentence the researchers once heard. "What kind of art the accounting is?" was a question the researchers had and was finally illustrated in the process of this research. "Art is associated with spontaneous improvisation and spontaneous effect" is a statement from Panuti Sudjiman (1990: 37). In relation to that, the researchers considered the practice of informal accounting information systems was not constructed from procedural and systematic systems, but built through the practice of "art". J. Julia in her book entitled Anthology of Art Education and Local Wisdom Potential stated that "the root of art is beautiful". Beauty is the initial idea of a work of art creation, howsoever the beauty forms. Was it wrong if the researchers felt a form of beauty in the work practices of accounting information systems?

\section{CONCLUSION}

The practice of accounting information system in BPKAD of Barito Kuala Regency was not always related to systematic procedures and accounting information was not always generated through a computerized system. The practice of accounting information systems involving human resources (i.e. accountant staffs) triggered the practice of informal accounting information systems emphasizing more on communication from and for people within the organization.

Thus, the results of this study found that informal accounting information systems in the public sector are a system with no written procedures and policies, but conducted spontaneously, without any arrangement and agreement within the organizational structure. Informal accounting information systems in the public sector were conducted through interactions among staffs, discussions in an unplanned meeting, and the use of social media as a means of coordination. In addition, informal accounting information systems in the public sector were also practiced through improvisations such as the use of personal notes, reporting schedules creation, and financial reporting checklists aimed at supporting the effectiveness of accounting information system practices.

In addition, the researchers considered it was important to do a reflection on the research result. This was done so that the research result not only enriched the academic science but also improved the faith or belief of the researchers toward the more fundamental awareness. Slightly quoting a statement from Prof. Iwan Triyuwono: "Scientific research is a study that once I read, it will bring me closer to my God".

Therefore, the researchers tried to reflect on the findings of the practice of information systems informal accounting. The existing interactions between the staffs restore the awareness of the researchers about the relationship between human beings, which is known as Hablum Minannas in Islam. The researchers considered the interaction is a form of Islamic concept consciously or unconsciously applied in work. With the interaction in practice, informal accounting information systems produce a "sense" in the organization. Moreover, in Islamic point of view, the researchers considered an application of Allah's 99 asthma, i.e. Al-Haadi (The Giver of Guidance), was found in the practice of informal accounting information systems through improvisation by accountant staffs. It meant that improvisation by accountant staffs was the actualization of the instructions given by Allah in a perfection attempt regarding the practice of accounting information systems.

\section{REFERENCES}

1. Berger, P. L. \& Luckmann, T. 1966. The Social Construction of Reality. London: Doubleday. 
2. Burns, T. 1969. On the Plurality of Social Systems, in Burns, T. (ed.) Industrial Man. Harmondsworth: Penguin.

3. Button, G., Martin, D., O'Neill, J., dan Colombino, T. 2012. Lifting the Mantle of Protection from Weber's Presuppositions in His Theory of Bureaucracy. Human Studies 35, 235-262.

4. Guba, Egon G., dan Lincoln, S. Yvona. 1989. Fourth Generation Evaluation. San Framcisco. Jossey-Bass.

5. Mintzberg, H. 1975. Impediments to the Use of Management Information. New York: National Association of Accountants.

6. PrestonAlistair. 1986. "Interactions And Arrangements In The Process Of Informing*"AccountingOrganizations and Society, Vol. 11, No. 6, pp. 521-540.

7. Roberts, J., dan Scapens, R. 1985. Accounting systems and system of accountability understanding accounting

8. Vickers, M. H. 1999. Information technology development methodologies: Towards a non-positivist, developmental paradigm. The Journal of Management Development 18(3), 255-272.

9. Wijaya, R.E and Ludigdo, U. 2015. Paradigm Blurred: Opera Cake in Management Accounting Information Research. Social and Behavioral Sciences 211, 859-865. 